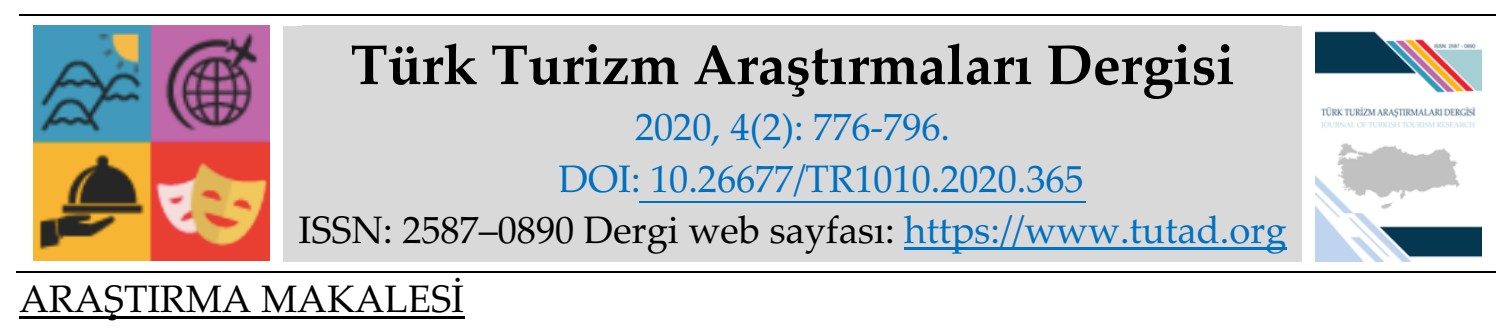

\title{
Turizm Destinasyonlarında Turistin Temsilcisi Olarak Yerleşik Yabancıların Yerel Halk ile Sosyal Etkileşimleri ve Sosyal Etkileşimde Kalış Süresinin Etkisi*
}

Öğr. Gör. Dr. Gizem ÖZGÜREL, Muğla Sıtkı Koçman Üniversitesi, Marmaris Turizm MYO,

Muğla, e-posta: gizemozgurel@mu.edu.tr

ORCID: https://orcid.org/0000-0002-1161-3721

Prof. Dr. Cevdet AVCIKURT, Balıkesir Üniversitesi, Turizm Fakültesi, Balıkesir, e-posta: avcikurt@balikesir.edu.tr

ORCID: https://orcid.org/0000-0002-9169-9767

Öz

Çalışmada, turist ile aynı kökenden olan Marmaris'e yerleşmiş Birleşik Krallık kökenli yerleşik yabancılar ile Marmaris yerel halkı arasındaki sosyal ilişkilerin olumlu düzeyde olup olmadığ ya da ne derece olumlu olduğu araştırılmıştır. Yerleşik yabancıların yerel halk ile olan sosyal etkileşimlerinde destinasyondaki kalış süresinin bir etkisi var mı? sorusu cevaplandırılmaya çalışılmıştır. Çalışmada nicel araştırma yöntemi benimsenmiş, 382 yerleşik yabancıdan gereksinim duyulan veriler toplanmıştır. Çalışmadan elde edilen bulgular; Marmaris'te yerleşik yabancı-yerel halk ilişkisinin olumlu, kaliteli, samimi bir biçimde gerçekleştiğini, yerleşik yabancıların yerel halk ile etkileşimlerini yüksek düzeyde önemsediklerini ve temaslarından yüksek düzeyde memnun olduklarını göstermektedir. Çalışmada turistin temsili olarak kabul edilen yerleşik yabancıların, destinasyondaki kalış sürelerinin artmasının sosyal etkileşimleri üzerinde bir etkisi olmadığı tespit edilmiştir. Söz konusu bulgular, turist-yerel halk çatışma ve uyumsuzluklarının kalış süresinden bağımsız olarak kültürel farklılıklardan kaynaklandığı savını desteklemektedir.

* Bu makale, Balıkesir Üniversitesi Sosyal Bilimler Enstitüsü Turizm İşletmeciliği ABD’da yürütülmüş, “Turizm Destinasyonlarında Yerleşik Yabancı-Yerel Halk Etkileşimi Üzerine Bir İnceleme" adlı doktora tezinden üretilmiştir.

Anahtar Kelimeler: Kalış Süresi, Marmaris, Turizm Destinasyonu, Sosyal Etkileşim, Yerleşik Yabanc1.

Makale Gönderme Tarihi: 16.12.2019

Makale Kabul Tarihi: 02.04.2020

\section{Önerilen Atıf:}

Özgürel, G. ve Avcıkurt, C. (2020). Turizm Destinasyonlarında Turistin Temsilcisi Olarak Yerleşik Yabancıların Yerel Halk ile Sosyal Etkileşimleri ve Sosyal Etkileşimde Kalış Süresinin Etkisi, Türk Turizm Araştırmaları Dergisi, 4(2): 776-796.

(C) 2020 Türk Turizm Araştırmaları Dergisi. 


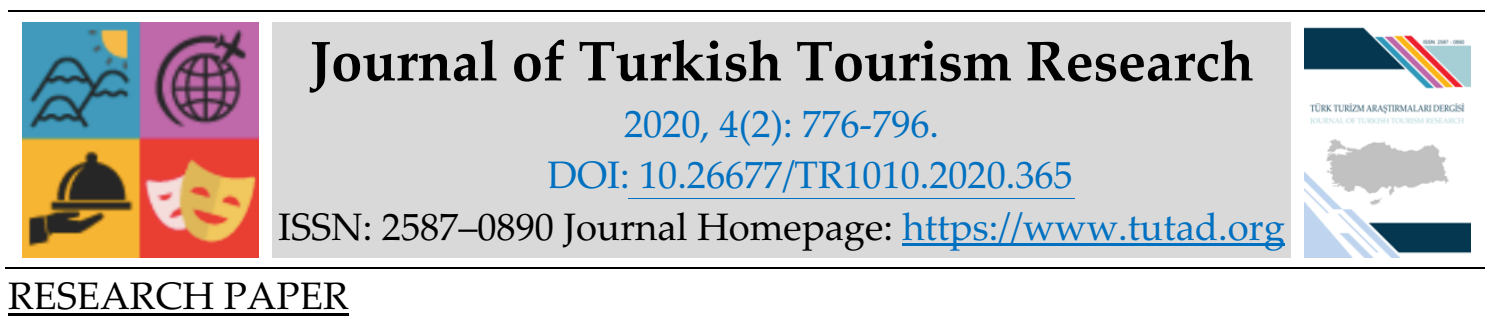

\title{
Social Interactions of Foreign Residents as Tourist Representatives with Local People in Tourism Destinations and The Impact of Length of Stay in Social Interaction
}

Dr. Gizem ÖZGÜREL, Muğla Sıtkı Koçman University, Marmaris Tourism Vocational School, Muğla, e-mail: gizemozgurel@mu.edu.tr ORCID: https://orcid.org/0000-0002-1161-3721

Prof. Dr. Cevdet AVCIKURT, Balıkesir University, Faculty of Tourism, Balıkesir, e-mail: avcikurt@balikesir.edu.tr ORCID: https://orcid.org/0000-0002-9169-9767

\begin{abstract}
In this study, it has been investigated whether the social relations between the resident foreigners who are settled in the same origin as the tourists who are originally from the UK and the local people of Marmaris are positive or to what extent they are positive. It was sought to answer the question of whether there is an effect of the length of stay in the destination on the social interaction of the resident foreigners with the local community. In the study, quantitative research method was adopted and data were collected from 382 resident foreigners. According to the findings of the study, the foreign-local people relationship established in Marmaris is realized in a positive, high quality, sincere manner, the resident foreigners attach great importance to their interactions with the local people and they are highly satisfied with their contacts. It was found that the increase in the duration of the stay in the destination has no effect on social interaction. These findings support the argument that tourist-local population conflicts and discrepancies stem from cultural differences regardless of length of stay.
\end{abstract}

Keywords: Length of Stay, Marmaris, Tourism Destination, Social Interaction, Resident Foreigners.

Received: 16.12 .2019

Accepted: 02.04.2020

\section{Suggested Citation:}

Özgürel, G. and Avcikurt, C. (2020). Social Interactions of Foreign Residents as Tourist Representatives with Local People in Tourism Destinations and The Impact of Length of Stay in Social Interaction, Journal of Turkish Tourism Research, 4(2): 776-796.

(C) 2020 Türk Turizm Araştırmaları Dergisi. 


\section{Gíriş}

Küresel ölçekte yaşanan gelişmeler, turizm destinasyonlarını uluslararası insan akışlarının hedefi haline getirmiştir. Farklı milliyetlerden insanlar turizm destinasyonlarında; turist, turizm çalışanı, yerel halk ve yerleşik yabancı gruplarını oluşturmakta, aralarındaki sosyal, kültürel, ekonomik ilişkiler ve etkileşimler hem bireysel hem de toplumlar arası yarattığı etkiler nedeniyle, son yıllarda araştırılan ve açıklanmaya çalışan konular arasında yerini almaya devam etmektedir. Turizm destinasyonlarında özellikle turist-yerel halk ilişkilerinin olumlu olması, turistin tatil deneyiminden tatmin olmasında, destinasyonu tekrar ziyaret etmesinde, yerel halkın ise turiste daha yüksek düzeyde tolerans göstererek, turizme ve turizm gelişimine yönelik olumlu tutum ve davranışlar içerisine girmesine neden olmaktadır. Turist-yerel halk ilişkilerinin belirleyicisi olan çok sayıda faktör bulunmaktadır. Turistleri etkileyen faktörler arasında; fiziksel, etnik, demografik, ekonomik özellikleri, sayıları, kültürel mesafeleri, aktivitelerden faydalanma yoğunlukları ve destinasyonda kalış süreleri yer almaktadır.

Çalışmada, "yerleşik yabancı-yerel halk etkileşimini", "turist-yerel halk ilişkisi" konusunun bir temsilcisi gibi ele alarak, turist-yerel halk ilişkilerinin belirlenmesinde rol oynadığı düşünülen, ama doğrudan doğruya gözlenemeyen faktörlerden biri olan "kalış süresinin" gerçekten etkili olup olmadığının, yerleşik yabancı-yerel halk ilişkilerine bakılmak suretiyle ortaya çıkarılmaya çalışılmıştır.

Turistin kalış süresinin kısalığının yerel halk-turist ilişkisi üzerindeki etkisi konusunda ilk akla gelen, bu etkinin olumsuz olduğudur ki, turizm zaten yerleşmeye yönelik olmayan kısa süreli seyahatler olarak tanımlanmaktadır (Urry, 2009:16). Kalış süresinin kısalığının olumsuz etkisinin iki tür mekanizması olabileceği düşünülmektedir:

Birincisi, iki taraf arasındaki ilişki, turizmin karakteri icabı kısa süreli olduğundan, tarafların birbirlerine kötü davranmamak için gayret sarf etmeye çok gereksinim duymamaları olabilir. Başlı başına yerleşik yabanc1-yerel halk etkileşimi üzerine herhangi bir çalışmada, ilişkilerin olumlu olduğu saptandığı takdirde, bu saptama -kesin bir kanıt oluşturmamakla birlikte- bu hipotezi bir anlamda desteklemiş olur.

Kalış süresinin kısalığının ilişkilerin olumsuz olmasına sebep olabilmesini sağlayan ikinci tür mekanizma, turistlerin, kültür farklılığından kaynaklanan uyumsuzluklardan ders çıkararak, deyim yerindeyse- "kendilerine çeki düzen vermek için" yeterli zamana sahip bulunmamaları olabilir. Acaba kalış süresi biraz daha uzun olan turistlerin yöre halkı ile etkileşimi, kendilerine çeki düzen vermeye vakitlerinin olması nedeniyle daha olumlu olmakta mıdır? Eğer böyle bir şey gözlenebilirse, turist-yerel halk ilişkisi niteliğinin belirlenmesinde kalış süresinin etkisi tescil edilmiş olur; yok eğer arada bir farklılık saptanmazsa, kültür farklılıklarının -kalış süresinden bağımsız olarak- esas etkili faktör olduğu sonucuna varmak gerekmektedir. Fakat bir gerçektir ki, turistin kalış süresi göreceli olarak ne kadar uzun olursa olsun, yine de aslında kısadır. Sözgelimi gerek bir hafta gerekse iki hafta (iki hafta bir haftanın 2 katı olmasına rağmen) kısadır. Dolayısıyla göreceli olarak kalış süreleri farklı olan turistlerin düşünce ve duygularında ya da yerel halkın bunlarla ilişkileri hakkındaki düşüncelerinde süreye göre bir farklılık gözlemeyi beklemek güçtür. Bunun yanı sıra, zaten kısa süre için gelmiş olan yabancıya, sözgelimi, "yerel halkla yemeğinizi paylaşır mısınız?" türünden sorular sormak da çok anlamlı olmayabilir. Kalış süresinin etkisini ölçmek için, bir hafta ile iki haftayı karşılaştırmak yerine, sözgelimi 6 aydan beri kalmakta olanlarla 1 yıldan beri kalmakta olanlar üzerinde bir araştırma yapılması (ki, bu durumda artık yabancı "turist" değil, "yerleşik" olmaktadır) daha anlamlı olabilir. Daha az 
ikâmetin daha fazla uyumsuzluğa işaret ettiği saptandığı takdirde, bu durum turistin yerel halk ile anlaşmazlıklarının da -karakter olarak- destinasyonda "geçici" olmasından kaynaklandığ hakkında bir ipucu olarak kabul edilebilir. Nitekim literatürde turist-yerel halk ilişki ve etkileşiminde teorik bir çerçevenin olmaması turist-yerel halk çalışmalarını sınırlandırmış (Zhang vd., 2006:191) ve turist-yerel halk etkileşimini kesin bir şekilde ölçmek için yeterli bilgi olmadığı yapılan çalışmalarda belirtilmiştir (Reisinger ve Turner, 2003:64; Carneiro vd., 2018:6). $\mathrm{Bu}$ nedenle, turist-yerel halk etkileşimini etkileyen etmenleri, aralarındaki etkileşimi ve etkileşimin sonuçlarını anlamak için literatürü genişletmenin önemli olduğu bazı çalışmalarda belirtilmiştir (Pizam vd., 2000:396; Sinkovics ve Penz, 2009:458). Söz konusu "genişletmenin" yollarından birisinin, "turistin" bir çeşit temsilcisi olarak "yerleşik yabancının" kullanılması olduğu düşünülerek, çalışma kapsamında inceleme konusu yapılmıştır. Buna bağlı olarak bu çalışmada, bir turizm destinasyonu olan Marmaris'teki yerleşik yabancı ve yerel halk arasındaki sosyal etkileşim incelenmiştir. Çalışmada, yerel halk ile Marmaris'te yaşayan ve köken ülkeleri Türkiye olan Türkiye Cumhuriyeti vatandaşları, yerleşik yabancılar ile Marmaris'te kiraladığı ya da satın aldığ 1 konutta 6 ay ve üzerinde bir süre ikamet eden, T.C. kanunlarına göre göçmen sayılmayan, Marmaris halkı tarafından yabancı olarak görülen, köken ülkesi Birleşik Krallık (İngiltere, Kuzey İrlanda, Galler ve İskoçya) olan Birleşik Krallık vatandaşları ile Türkiye'ye yerleştikten sonra Birleşik Krallık vatandaşlığı yanı sıra ikinci vatandaşlık olarak Türkiye Cumhuriyeti vatandaşlığını alan yabancılar ifade edilmiştir.

Çalışmada turizm destinasyonlarında yaşanan sosyal ilişki ve etkiler, karşılıklı sosyal etkilerin yarattığı sosyal etkileşimde kalış süresinin etkisi kavramsal çerçeve başlığı altında açıklanmaya çalışılmıştır. Çalışma için nicel araştırma yöntemi benimsenmiş, Marmaris destinasyonuna yerleşmiş Birleşik Krallık kökenli 382 katılımcıdan gereksinim duyulan veriler toplanarak, analiz edilmiş, elde edilen bulgular tartışılarak, sonuç ve öneriler geliştirilmiştir.

\section{KAVRAMSAL ÇERÇEVE}

\section{Turizm Destinasyonlarında Sosyal İlişki ve Etkiler}

Turizmin öznesini oluşturan turistin, çeşitli turistik gereksinim ve isteklerini gerçekleştirdiği, varış yerinin ötesinde, turistik deneyimlerin edinildiği mekânlar turizm destinasyonlarıdır. Söz konusu mekânlar; turizm ekseninde yaşanan ilişki ve etkileşimlerin yarattı̆̆ı, hem fiziki özellik gösteren, hem de turistlerin zihninde yaratılmış soyut mekânlardır.

Uluslar arası turizm hareketleri, turizm destinasyonlarında farklı toplumların karşılaşmasını ve temasını içeren sosyal ve kültürel ortamlar yaratmaktadır. Bu karşılaşma ve temasın; bir tarafında daha iyi bilinen, istikrarlı bir nüfus olan yerel halk; diğer tarafında ise değişken olan ve önceden bilinmeyen turistler yer almakta ve aynı turistik ortam/mekân içerisinde bulunmaktadır (Bimonte, 2008:457). Turizm destinasyonlarında; turist-yerel halk, turist-turizm çalışanı, turistturist, turist-yerleşik yabancı, yerleşik yabanc1-yerel halk karşılaşmaları, sosyal ilişkileri ve etkileşimleri gerçekleşmektedir.

Birbirinin farkında olan, en az iki birey arasında belirli bir süre devam eden, belirli bir amacı gerçekleştirmeye odaklanarak kurulan anlamlı ilişkiler, sosyal ilişki olarak tanımlanmaktadır (Konuk, 2017:38; Bahar, 2009:33). Sosyal ilişki için; en az iki kişinin olması, tarafların birbirinin farkında olması, ilişkinin bir anlam içermesi ve belirli bir zaman dilimini kapsaması gerekmektedir. Turizm destinasyonunda toplumsal karşılaşma ve temaslar; bireylerin birbirlerini fark etmeleri ile başlamakta, uzaklaşmalarıyla sona ermektedir. Karşılaşmaların ve temasların; amacı, toplumsal fonksiyonu, karşılaşan grupların türü ve sayısı, karşılaşma ve temas ortamı açısından birbirinden farklılık göstermektedir (Goffman, 2017:10-15). 
Turizm destinasyonlarında turist; gereksinimlerini karşılamak üzere mal ve/veya hizmet satın alırken, aynı alanı, çekim yerini veya tesisi kullanırken (sokak, plaj, turizm işletmeleri vb.), bilgi veya fikirlerini zenginleştirmek amacıyla birçok farklı ortamda bulunmaktadır (Kastenholz vd., 2013:370; Rızaoğlu, 2012:316; Reisinger ve Turner, 2003:38). Turizm destinasyonlarında turistlerin sosyal ilişkilerinin büyük çoğunluğu alışveriş mekânları, plajlar, restoranlar, oteller, havaalanları, yüzme havuzları, meydanlar, sokaklar, turistik çekim yerleri, yerel etkinlikler, sinema/konser vb. eğlence merkezleri, çarşı/pazar gibi çeşitli kamuya açık ortamlarda gerçekleşmekte (Urry, 2009:239) iken, yerleşik yabancı tüm bu ortamlar yanında aynı mahallede, sitede, apartmanda, evde yerel halk ile temas ederek sosyal ilişkilerini geliştirme ortamlarına sahip olmaktadır.

Turizm destinasyonuna yerleşen yabancı, kendisine göre daha farklı bir görünüme sahip, farklı dil, din, örf, adet, yeme-içme gibi folklorik özellikler gösteren yerel halk ile sürekli karşılaşmakta ve temas etmektedir. Yerleşik yabancı da tıpkı turist gibi; karşılaşma ve temas yaşadığı yerel halk ile kendisi arasındaki farklılıkları, yerel halkın zamanı ve mekânı nasıl kullandığını, nasıl davranışlar sergilediğini, dünyayı nasıl algıladıklarını gözlemleyerek (Avcıkurt, 2007:134), gündelik yaşam içerisinde, kendisi de bu yaşamın bir parçasını oluşturarak deneyimlemektedir. Sosyal ilişkiye giren yerleşik yabancı ve yerel halkın karşılıklı olarak birbirlerinden haberdar olmaları, sevgi-işbirliği kurma duygularıyla veya düşmanlık-zıtlaşma duygularıyla gerçekleşmektedir (Güney, 2016:71).

Toplum içerisinde bireylerin birbirlerine, dikkatlerini, sevgilerini, zamanlarını, bağlılıklarını vermesini sağlayan temel etmen sosyal etkidir. Sosyal etki kavramını, bireyin ya da birey gruplarının diğerini/diğerlerini herhangi bir konudaki tutum, duygu, düşünce ve davranışlarını etkileme çabası olarak tanımlamak mümkündür (Demir Özcan, 2017:281). Yerleşik yabancı-yerel halk etkileşimi; turizm destinasyonlarında yerleşik yabancı ve yerel halk arasında gündelik yaşamın bir parçası olarak ortaya çıkan, karşılıklı etkiler yaratan toplumsal ilişkidir. Bireylerin yerleşik yabancı ve yerel halk olarak yer aldığı mekânlar sosyolojik sistemde, sosyal etkileşimin gerçekleştiği katmanlardır, bir başka ifade ile sosyal etkileşim katmanlarını oluşturmaktadır. Farklı görüş, düşünce, yaşam biçimi, inanç, dil ve kültürlere sahip bireylerin yerleşik yabancı ve yerel halk olarak ilişkide bulunması, "yerleşik yabancı-yerel halk ilişkisi" olarak adlandırılan bir toplumsal ilişki biçiminin doğmasına ve birbirlerini karşılıklı olarak etkilemeleriyle "yerleşik yabancı-yerel halk etkileşimi" olarak ifade edilebilen etkileşim durumunu ortaya çıkarmaktadır.

Yerleşik yabancı-yerel halk sosyal etkileşim biçimlerini, sosyal ilişki biçimlerinden yola çıarak resmi olmayan (informel) ve resmi (formel) etkileşim olarak sınıflandırmak mümkündür. İnformel (resmi olmayan) etkileşim, yakın etkileşim ve cazibe merkezleri ile tesislerde gerçekleşen etkileşim; resmi (formel) etkileşim ise işyerinde etkileşim alt başlıkları altında aşağıda Tablo 1'de gösterilmektedir.

Resmi Olmayan (İnformel) Etkileşim: Yüz yüze, yardımlaşma, dostluk, samimiyet, konukseverlik ve sevgi duygusunun hâkim olduğu, gönüllü ilişkilerin karşllıklı etkisi sonucu gerçekleşen etkileşimdir. Aynı zamanda benzer yaşam biçimine sahip kişiler arasında; aile, akrabalık ile komşuluk kümelerinde gerçekleşen, birincil küme özelliği gösteren bir etkileşim biçimidir (Bahar, 2009:35). Resmi olmayan (informel) etkileşim; yerleşik yabancı ve yerel halkın tüm kişilik özelliklerini açıkça ortaya koyabildikleri, biz duygusunun hâkim olduğu, kaynaşma ve dayanışmanın yüksek seviyede gerçekleştiği bir etkileşimdir. Yerleşik yabancının yerel halktan birisiyle evlenmesi, akraba olması, arkadaş-dost olması, aynı apartman, site ya da mahallede komşuluk ilişkisi kurması biçiminde sosyal ilişki gerçekleşmekte, birbirlerini gündelik yaşam içerisinde etkilemektedirler. Yerleşik yabancı-yerel halk arasında kurulan gönüllü ilişkilerin, dostluğun dönüştürücü bir gücü bulunmakta, sosyal ağların genişlemesine ve zenginleşmesine katkı sağlayarak, olumlu sosyal etkileşim sağlanmaktadır. Yerleşik yabancıların 
resmi olmayan ilişki tercihlerinin, ev sahibi toplum ile aralarındaki ilişkinin boyutları konusunda önemli bir gösterge olarak değerlendirilebileceği düşünülmektedir. Özellikle yerleşik yabancının yerel halktan bir kişiyle evliliği, topluma entegrasyonun büyük oranda gerçekleştiğini göstermektedir (Göker, 2013:93).

Tablo 1. Yerleşik Yabancı-Yerel Halk Sosyal Etkileşim Biçimleri

\begin{tabular}{|c|c|c|}
\hline \multirow{2}{*}{ 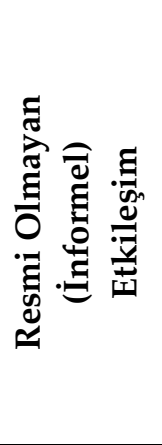 } & Yakın Etkileşim & $\begin{array}{l}\text {-Birbirlerini evlerine davet etme, } \\
\text {-Beraber spor yapma, } \\
\text {-Beraber partiye katılma, } \\
\text {-Yemeklerini paylaşma vb. }\end{array}$ \\
\hline & $\begin{array}{l}\text { Cazibe } \\
\text { Merkezlerinde ve } \\
\text { Tesislerde Etkileşim }\end{array}$ & $\begin{array}{l}\text {-Plajda iletişim kurma, } \\
\text {-Etkinliklerde temas kurma, } \\
\text {-Yiyecek-içecek işletmelerinde temas kurma, } \\
\text {-Diğer ticari kuruluşlarda temas kurma, } \\
\text {-Disko, kulüp ve barlarda temas kurma. }\end{array}$ \\
\hline 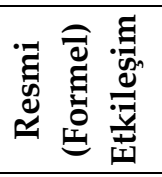 & İşyerinde Etkileşim & $\begin{array}{l}\text {-İşyerinde temas kurma, } \\
\text {-Resmi işler hakkında bilgi verme (belediye vb.), } \\
\text {-Ürün ya da hizmet sunarken/alırken etkileşim. }\end{array}$ \\
\hline
\end{tabular}

Kaynak: (Carneiro, Eusébio ve Caldeira, 2018:9).

Resmi (Formel) Etkileşim: Bireyler arasında yararcı ve çıkarcı bir temele dayanan, içtenliğin, duygusallığın ve yakınlığın olmadığı, belirli kurallar dizininde gerçekleşen, profesyonelliğin hâkim olduğu, ikincil küme özelliği gösteren ilişkilerin karşıllklı etkisi sonucu gerçekleşen etkileşimdir (Ergil, 1984:16). Resmi (formel) etkileşim; yüzeysel, kurallı biçimde, kamu dairelerinde, resmi konular ile ilgili kurulan temaslarda, ticari faaliyetlerle ilgili alışveriş işlemlerinde gerçekleşen, kişisel olmayan ilişkilerin yarattığı etkileri kapsamaktadır. Yerleşik yabancının turizm destinasyonunda gündelik yaşamını sürdürürken, belirli bir kurala bağlı olarak, resmi yerlerde, kamu kurum ve kuruluşlarında, iş ilişkilerini yürütürken gerçekleştirdiği, resmiyetin hâkim olduğu etkileşim biçimidir.

\section{Yerleşik Yabanc1-Yerel Halk Etkileşiminde Kalış Süresi}

Çalışma kapsamında yerleşik yabancının, tekrar getirilmek istenen turist ile eş değer tutulabileceği görüşü benimsenmiştir. Çalışmada; turist-yerel halk uyumsuzlukları, çatışma ve anlaşmazlıklarının kalış süresi ile ilişkisi merak edilmiştir. Acaba turist-yerel halk ilişkisinde uyumsuzluklar ne ölçüde kültür farkından, ne ölçüde kalış süresinin kısalığından kaynaklanıyor? sorusu araştırmaya değer bulunmuştur. Söz konusu durumu turistlere yönelik bir saha çalışması (anket) yaparak gözlemleme imkânı bulunmamaktadır. Çünkü; turist, yılın 6 ayı ve daha fazlası bir süre turizm destinasyonunda kalan yerleşik yabancıya göre, kısa (1 hafta15 gün vb.) bir süre turizm destinasyonunda bulunmaktadır. Yerleşik yabancı ise turist ile aynı kültürdendir ve turizm destinasyonunda daha uzun süre kaldığı için gözlemleyebilme şansına sahip olunmaktadır. Burada şöyle bir peşin yargıdan yola çıkılamayacağını belirtmek gerekmektedir. Yerleşik yabancı-yerel halk ile iyi anlaşmıyor olsaydı gelmezdi demek yanıltıcı bir ifade olabilir. Çünkü yerleşik yabancının destinasyona yerleşmesinde ekonomik nedenler başta olmak üzere toplumsal, politik, kültürel ve destinasyon imaj algısı gibi birçok nedenin 
varlı̆̆ının, göz ardı edilmiş olacağını belirtmek gerekmektedir. Yerleşik yabancıların yöreye yerleşme sebepleri arasında yerel halkın tutumu dışında kalan başka faktörlerin de yer aldığı ve "yerel halkın tutumu" faktörünün bu faktörler içerisinde sonuncu siralarda olduğunun başka çalışmalarda (Özgürel ve Avcıkurt, 2018:213) ortaya konulmuş olması peşin olarak böyle bir yargıya varılmasını engellemektedir. Yerleşik yabancı-yerel halk ilişkilerinin uyum/uyumsuzluk durumu etkileşimlerinin olumlu/olumsuz sonuçlanmasında etkilidir. Sosyal etkileşimin olumlu sonuçlanması; destekleyici karşılıklı ilişkiler sonucunda ortaya çıkmaktadır. Sosyal etkileşimin olumlu olması; birçok sosyal problemin azalmasına, topluluk ve yer duygularını güçlendirmeye, can ve mülk güvenliği hissini artırmaya, kişinin bulunduğu sosyal çevreyi daha kaliteli algılamasına, memnuniyet ve tatmin yaşamasına, sosyal etkileşime daha açık olmasına, sosyal mesafesinin azalmasına katkı sağlamaktadır. Dolayısıyla olumlu sosyal etkileşim; olumlu duygu, tutum, davranış geliştirmeyi desteklemekte (Smith 2011:7), yerleşik yabancının turizm destinasyonundaki toplumsal yaşayışa, kurallara uyum sağlamasına, entegrasyonuna ve çoğulcu bir toplum deneyimine başarılı bir biçimde katılmasına katkı sunmaktadır (Göker, 2013:93). Yerleşik yabancı-yerel halk arasında olumsuz sonuçlanan etkileşim ise; engelleyici karşılıklı ilişkilerin sonucunda ortaya çıkmaktadır. Sosyal etkileşimin olumsuz sonuçlanması; dışlanmaya, yabancı hissetmeye, içine kapanmaya, kişinin istenmediğini düşünmeye başlamasına, sosyal ve kültürel mesafesinin artmasına, yaşam kalitesinin düşmesine, topluluk duygusunun azalmasına neden olmakta, dolayısıyla olumsuz duyguların, tutum ve davranışların ortaya çıkmasında rol oynamaktadir.

Literatürde; sosyoloji ve turizm disiplinlerince sosyal ilişkiler ve etkileşimler ile ilgili yapılan çalışmalardan bazıları aşağıda sunulmuştur.

Mouratidis (2018) çalışmasında, kentsel yapının genel olarak sosyal refah üzerindeki etkisini sosyal hayata ve kişisel ilişkilere odaklanarak açıklamaya çalışmıştır. Çalışması için verileri, 1344 mahalle sakininden ve 10 derinlemesine görüşme yaptığı katılımcıdan toplamıştır. Oslo'da; kent merkezinde, yüksek nüfus yoğunluklu yerleşimlerdeki semt sakinlerinin aralarında daha az ilişki olmasına rağmen, kent merkezinden uzak düşük nüfus yoğunluktaki semtteki sakinlere göre; kişisel ilişkilerden önemli ölçüde memnun oldukları, daha geniş yakın ilişkiler ağına sahip bulundukları, daha aktif sosyal yaşama, daha güçlü sosyal desteğe ve tüm bunların yarattığı etki sonucu genel sosyal refah düzeylerinin daha yüksek olduğu sonuçlarına ulaşmıştır.

Carneiro ve arkadaşları (2018) çalışmalarında; turist-ev sahibi etkileşimini (yoğunluk ve memnuniyet) ve turizmin yerel halkın yaşam kalitesi üzerindeki etkisini tespit etmeye çalışmışlardır. Araştırmacılar Portekiz'de bulunan Barra ve Costa Nova kıyı turizm destinasyonlarından her birinden 175 'er katılımcıya ulaşarak, verileri toplamışlardır. Elde ettikleri sonuçlara göre; ev sahibi toplumun turistlerle yoğun ve memnuniyet verici bir etkileşim içerisinde olmalarının yaşam kalitelerine yönelik algıları üzerinde önemli bir rol üstlendiğini belirtmişlerdir.

Wang ve arkadaşları (2017) çalışmalarında, Çin Şangay'da kırsal bölgelerdeki göçmenler ile kentli yerel halk arasındaki komşuluk sıklığı ve yapısal özelliklerin duygusal ilişkilerini etkileyip etkilemediğini araştırmışlardır. 1420 katılımcıdan elde ettikleri verilere göre; katılımcılardan grup dışı insanlarla daha fazla etkileşimde bulunan bireylerin komşularıyla ilişkilerini daha şefkatli ve arkadaş canlısı olarak nitelendirme eğiliminde oldukları ve konut sahibi olanların grup dışı komşularıyla paylaştıkları ortak kimlikleri, benzer statüleri nedeniyle güçlü duygusal ilişkileri bulunduğu sonuçlarına ulaşmışlardır. Ayrıca iş̧̧i sınıfı mahallerinde yaşayan katılımcıların karşılıklı güveni kolaylaştırmak için gruplar arası komşuya güvenme eğiliminde oldukları araştırmacıların elde ettikleri bulgulardan bir diğeridir.

Capistrano ve Weaver (2017) çalışmalarında; Yeni Zelanda'daki Filipinli göçmen ev sahibi aileler ve onların Filipin'den ziyarete gelen akrabalarının etkileşimlerini ve deneyimlerini sosyal 
mübadele (değişim) teorisi ışı̆̆ında incelemişlerdir. Nitel araştırma yönteminin benimsendiği çalışmada, derinlemesine görüşmeler yapılmıştır. Araştırmacılar çalışmalarında Filipinli göçmen 11 aile (toplam 28 kişi) ve akrabalarını ziyarete gelmiş 17 Filipinliden verileri toplamışlardır. Filipin kültürüne yönelik yapılmış çalışmalardan ve sosyal mübadele (değişim) teorisinden yararlanılarak araştırmadan elde edilen bulgulara göre; Filipinli göçmenler ve ziyaretlerine gelen akrabaları arasındaki aile ilişkilerinin karşılıklı bağımlılığı ve etkileşimi gösterdiği, aile yükümlülüklerini karşılıklı olarak yerine getirdikleri sonuçlarına araştırmacılarca ulaşılmıştır.

Lee ve arkadaşları (2016) çalışmalarında; sosyal etkileşim bağlamında spor etkinliklerinde gönüllü deneyimlerini, gönüllülerin takım üyesi değişimlerini ve gelecekteki niyetleri üzerindeki etkilerini ortaya çıkarmaya çalışmışlardır. Amerika Birleşik Devletleri'nde Kuzey bölgesinde spor etkinlikleri gönüllerinden 150 katılımcıya ulaşarak, araştırmacılar verileri toplamışlardır. Elde ettikleri bulgulara göre, çevrimiçi sosyal etkileşim bağlarının ekip üyeliğini önemli ölçüde etkilediği, bu durumun katılımcıların gönüllülüğü tekrarlama niyetlerini etkilediği, aynı zamanda potansiyel gönüllülere gönülllük deneyimlerinin olumlu ağızdan kulağa iletişim yoluyla yayıldığı sonuçlarına ulaşmışlardır.

Wu ve arkadaşları (2013) çalışmalarında; sosyal etkileşimlerin turizme katılım üzerindeki etkisini incelemişlerdir. Araştırmacılar, çalışmalarında Japonya'daki 1253 katılımcıya çevrimiçi anket yaparak, verileri toplamışlardır. Sosyal etkileşimi içsel, dişsal ve ilişkili etkiler olarak 3 tipe ayıran araştırmacılar, içsel sosyal etkilerin turizm katılım davranışları üzerinde önemli etkileri olduğu sonucuna ulaşmışlardır.

Öztürk ve Özaslan (2013) “Orta öğretim öğrencilerinin yabancı turistlere ilişkin tutumlar üzerine bir inceleme" isimli çalışmalarında, turizm eğitimi alan öğrencilerin turistler ile olan sosyal mesafelerinin kısa, sosyal etkileşimlerinin ise yüksek olduğu sonucuna ulaşmışlardır.

Weaver ve Lawton (2001) çalışmalarında; yerel halk-turist etkileşiminin turizme yönelik tutum üzerine etkisini araştırmışlar, turistlerle daha kapsamlı teması olanların, turizm yanlısı tutumları ifade etme olasılıklarının daha yüksek göründüğü, destinasyona sonradan (yeni) gelenlerin turizmde çalışma, turistlerle daha sık temas ve toplumu yerel olmayanlarla paylaşma arzularını ifade etme olasılığının daha yüksek olduğu sonuçlarına ulaşmışlardır. Araştırmacılar; turizm ve turistlerle ilgilenenlerin turizm sektörüne daha olumlu bir biçimde eğileceği ve destinasyonda uzun süredir ikamet eden ancak turizme adapte olmamış olanların ise olumsuz tutumları barındıracağı sonuçlarına ulaşmışlardır.

Turizm destinasyonlarına yerleşen yabancıların yerel halk ile etkileşimleri üzerine yapılmış yok denecek kadar az sayıda çalışmaya rastlanılmış (Xu vd., 2017), ikamet ya da kalış sürelerinin etkileri ile ilgili bir çalışmaya ulaşılamamıştır.

Yukarıdaki öngörüler doğrultusunda Marmaris destinasyonunda yerleşik yabancı-yerel halk ilişkileri ve etkileşimleri ne kadar olumlu? ve kalış süresi ne kadar etkili? söz konusu soruların cevaplarının araştırıldığı çalışmada benimsenen yöntem ve elde edilen bulgular devam eden kısımda sunulmaktadır.

\section{YÖNTEM}

Araştırmada nicel yöntem benimsenmiş, elde edilen veriler SPSS (Statistical Package for Social Sciences) for Windows 22.0 programı kullanılarak analiz edilmiştir. Verilerin değerlendirilmesinde tanımlayıcı istatistiksel yöntemleri olarak sayı, yüzde, ortalama, standart sapma kullanılmıştır. Ölçeğin Türkçe adaptasyon çalışmalarında doğrulayıcı faktör analizleri ve iç tutarlılık katsayısı olarak cronbach alpha hesapları yapılmıştır. Yerleşik yabancılarda sosyal 
etkileşim, temastan duyulan memnuniyet tek örnekte t-testi ile sosyal etkileşim puanlarının kalış süresine göre farklılaşma durumunda tek yönlü varyans analizi uygulanmıştır.

Araştırmanın evrenini Muğla ili Marmaris ilçesine yerleşmiş, köken ülkesi Birleşik Krallık olan, yerleşik yabancılar oluşturmaktadır. İlçede ikâmetli olarak toplam 2.843 yabancı uyruklu bulunmakta, yabancı uyrukluların 1.082'sini Birleşik Krallıktan gelenler oluşturmaktadır (Göç Politika ve Projeleri Daire Başkanlığı, 2016). Araştırmanın örnekleminden kartopu örnekleme yöntemi ile veriler elde edilmiştir. Kartopu örnekleme; ana kütle içinde yer alan, araştırmacının ulaşabildiği ilk kişiden elde edilen veriler doğrultusunda, sonraki kişiye ve zincirleme biçimde diğer kişilere ulaşarak, örneklem hacminin kartopu gibi büyütülmesidir. (Ural ve Kıllç, 2018:40). Örneklem büyüklüğü Salant ve Dillman'nın (1994:55) belirlediği formül ile hesaplanmıştır. Formül ve formülde yer alan sembollerin açıklamalarına aşağıda yer verilmiştir.

$$
\underline{\mathrm{n}}=\mathrm{N} \mathrm{t}^{2} \mathrm{pq} / \mathrm{d}^{2}(\mathrm{~N}-1)+\mathrm{t}^{2} \mathrm{pq}
$$

N: Hedef kitledeki birey sayısı

n: Örnekleme alınacak birey sayısı

p: İncelenen olayın görülüşs sıklığı (gerçekleşme olasıllı̆ı)

q: İncelenen olayın görülmeyiş̧ sıklığı (gerçekleşmeme olasılı̆̆ı)

$\mathrm{t}$ : Belirli bir anlamlllık düzeyinde, $\mathrm{t}$ tablosuna göre bulunan teorik değer

d: Olayın görülüş sıklığına göre kabul edilen \pm örnekleme hatasıdır.

Yerleşik yabancı üzerinde örneklem formülü kullanılarak homojen bir yapıda olmayan bu evren için \% 95 güven aralığında, $\pm \% 5$ örnekleme hatası ile gerekli örneklem büyüklüğü $n=1082(1,96) 2$ $(0,5)(0,5) /(0,5) 2(1082-1)+(1,96) 2(0,5)(0,5)=284$ olarak hesaplanmıştır. Verilerin toplanmasında anket tekniği kullanılmıştır.

Bu çalışmada; üretildiği doktora tezinde yer alan, literatürden derlenen, uzman görüşü alınan, redaksiyonu yapılan, pilot uygulaması ve saha uygulaması gerçekleştirilen; topluluk duygusu, sosyal mesafe, yaşam kalitesi, sosyal etkileşim ve turizm yönelik tutum ölçeklerinden, 14 ifadenin yer aldığıı, 3 alt boyutun bulunduğu, sosyal etkileşim ölçeği ve katılımcıların demografik özelliklerinin yer aldığ 8 adet ifadeye verilen cevaplar sunulmuştur.

Çalışmada yararlanılan sosyal etkileşim ölçeği, Carneiro ve Eusébio (2015:29) tarafından turizm bağlamında, sosyal temas ile ilgili literatür taraması yapılarak, etkileşimi temsil eden 13 ifadeden oluşturulmuştur. Sosyal etkileşim ölçeğinde yer alan yakın etkileşim boyutu (5 ifade), turizm çekicilikleri ve destek hizmetlerinde gerçekleşen etkileşim boyutu (5 ifade), resmi (formel) etkileşim boyutu (3 ifade) ile ölçülmüştür. Carneiro ve Eusébio (2015) sosyal etkileşimi, 7'li Likert tipi ölçek ile etkileşim sıklığ ( 1 "asla"dan 7 "çok sık"a) ve sosyal temastan duyulan memnuniyet düzeyi (1 “hiç tatmin olmamış" tan 7 "çok tatmin edici"ye) üzerinden ölçmüşlerdir. Çalışmada 5'li Likert tipi ölçek ile etkileşime verilen önem ( 1 “hiç önemli değil” den 5 “çok önemli"ye) ve sosyal temastan duyulan memnuniyet düzeyi (1 "tamamen memnuniyetsiz"den 5 "tamamen memnun"a) ölçülmüştür. Ölçekte yer alan boyutlar ve açıklamaları şunlardır:

- Yakın etkileşim: Yerleşik yabancıların yerel halk ile genellikle yakın temas halinde olduğu ve yerel halk ile daha derin bir ilişkiye katkıda bulunan eylemler gerçekleştirdikleri durumu açılamak için ifade edilen boyuttur. Yakın etkileşime örnek olarak yerleşik yabancıların yerel halkı evlerine davet etmeleri veya birbirleri ile hediyeleşmeleri verilebilir.

- Turizm çekicilikleri ve destek hizmetlerinde gerçekleşen etkileşim: Yerleşik yabanciların yerel halk ile yiyecek-içecek işletmelerinde, işyerinde, plajda vb. yerlerde temas ve ilişkileri sonucunda gerçekleşen etkileşimi ifade eden boyuttur.

- Resmi (formel) etkileşim (formal interaction): Yerleşik yabancıların yerel halk ile genellikle profesyonel faaliyetlerinden dolayı gerçekleştirdikleri etkileşimi ifade eden boyuttur. 


\section{Sosyal Etkileşim Ölçeği Madde Analizi Ön Uygulama Sonuçları}

60 yerleşik yabancı ile yapılan ön uygulama sonrasında sosyal etkileşim ölçeğinde bulunan 13 maddenin genel güvenirliğini hesaplamak için iç tutarlılık katsayısı olan "Cronbach Alpha" hesaplanmıştır. Ölçeğin genel güvenirliği alpha $=0.955$ olarak çok yüksek bulunmuştur. Ölçek maddelerine ilişkin madde analizi sonuçları aşağıda Tablo 2'de verilmektedir.

Tablo 2. Sosyal Etkileşim Ölçeği Madde Analizi (Ön Uygulama)

\begin{tabular}{|c|c|c|c|c|}
\hline Soru No & $\begin{array}{c}\text { Madde } \\
\text { Silindiğinde } \\
\text { Ölçek Puanı }\end{array}$ & $\begin{array}{c}\text { Madde } \\
\text { Silindiğinde } \\
\text { Varyans }\end{array}$ & $\begin{array}{c}\text { Madde Toplam } \\
\text { Korelasyonu }\end{array}$ & $\begin{array}{c}\text { Madde } \\
\text { Silindiğinde } \\
\text { Cronbach Alpha }\end{array}$ \\
\hline 1 & 50,025 & 127,554 &, 823 &, 950 \\
\hline 2 & 50,250 & 125,987 &, 843 &, 949 \\
\hline 3 & 50,250 & 128,206 &, 771 &, 951 \\
\hline 4 & 50,367 & 126,839 &, 753 &, 952 \\
\hline 5 & 50,233 & 123,962 &, 765 &, 951 \\
\hline 6 & 50,192 & 127,148 &, 863 &, 949 \\
\hline 7 & 50,317 & 124,000 &, 759 &, 952 \\
\hline 8 & 50,392 & 125,837 &, 884 &, 949 \\
\hline 9 & 50,183 & 125,546 &, 850 &, 949 \\
\hline 10 & 50,175 & 126,045 &, 669 &, 954 \\
\hline 11 & 50,342 & 127,907 &, 725 &, 952 \\
\hline 12 & 50,150 & 128,650 &, 674 &, 953 \\
\hline 13 & 50,217 & 130,961 & & \\
\hline
\end{tabular}

Genel güvenirlik ve madde analizleri sonuçlarına göre ölçek maddelerinin tutarlılık gösterdiği ve ölçeğe olan katkılarının yüksek olduğu anlaşılmıştır.

\section{Sosyal Etkileşim Ölçeği Doğrulayıcı Faktör Analizi}

Saha araştırması sonucunda sosyal etkileşim ölçeğinin daha önceden belirlenmiş faktör yapısı doğrulayıcı faktör analizi ile test edilmiştir. Doğrulayıcı faktör analize ilişkin diyagram aşağıda Şekil 1'de verilmektedir.

Doğrulayıcı faktör analizine ilişkin uyum iyiliği kriterleri aşağıda Tablo 3'te verilmektedir.

Tablo 3. Sosyal Etkileşim Ölçeği Doğrulayıcı Faktör Analizi İndeks Değerleri

\begin{tabular}{|l|c|c|c|}
\hline \multicolumn{1}{|c|}{ İndeks } & Normal Değer* $^{*}$ & ${\text { Kabul Edilebilir } \text { Değer }^{* *}}$ & Sosyal Etkileşim Ölçeği \\
\hline$\chi 2 /$ sd & $<2$ & $<5$ & 3,368 \\
\hline GFI & $>0.95$ & $>0.90$ & 0.90 \\
\hline AGFI & $>0.95$ & $>0.90$ & 0.90 \\
\hline CFI & $>0.95$ & $>0.90$ & 0.94 \\
\hline RMSEA & $<0.05$ & $<0.08$ & 0.07 \\
\hline RMR & $<0.05$ & $<0.08$ & 0.05 \\
\hline
\end{tabular}

* ** Kaynaklar: (Şimşek, 2007:4-22; Hooper ve Mullen 2008:53-60; Schumacker ve Lomax, 2004, 1-8; Waltz, Strcikland and Lenz, 2010:176-178; Wang ve Wang, 2012, 5-9; Sümer, 2000:49-74; Tabachnick ve Fidel, 2013:725). 


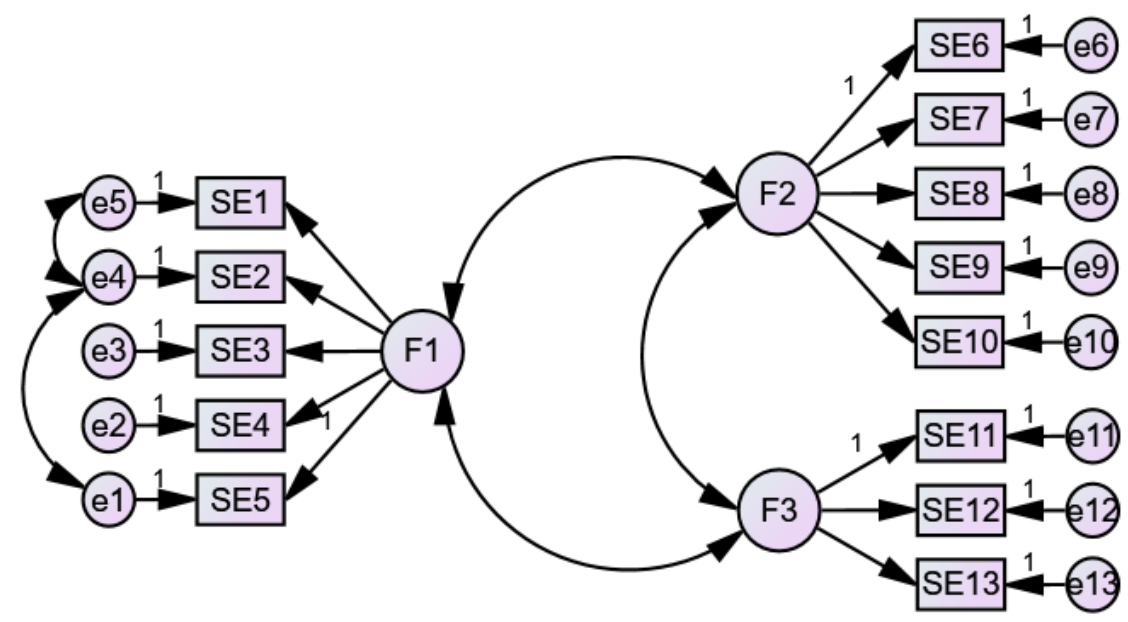

Şekil 1. Sosyal Etkileşim Ölçeği Doğrulayıcı Faktör Analizine İlişkin Diyagram (F1: Yakın Etkileşim, F2: Turizm Çekicilikleri ve Destek Hizmetlerinde Gerçekleşen Etkileşim, F3: Resmi/Formel Etkileşim)

Analiz sonuçları, doğrulayıcı faktör analizi ile hesaplanan uyum istatistiklerinin ölçeğin daha önce belirlenen faktör yapısı ile kabul edilebilir düzeyde uyumlu olduğu saptanmıştır. Standardize edilmiş faktör yükleri, $t$ değerleri ve maddelerin oluşturduğu açıklayıcılık $\left(\boldsymbol{R}^{2}\right)$ değerleri aşağıda Tablo 4 'te verilmektedir.

Tablo 4. Sosyal Etkileşim Ölçeği Faktör Yükleri ve Maddelere İlişkin Regresyon Katsayıları

\begin{tabular}{|l|c|c|c|c|c|c|c|c|}
\hline Maddeler & & Faktörler & $\boldsymbol{\beta}$ & Std. $\boldsymbol{\beta}$ & S.Hata & $\mathbf{t}$ & $\mathbf{p}$ & $\boldsymbol{R}^{\mathbf{2}}$ \\
\hline SE5 & $<---$ & F1 & 1,000 & 0,861 & & & & 0,516 \\
\hline SE4 & $<---$ & F1 & 0,905 & 0,793 & 0,032 & 28,708 & $\mathrm{p}<0,001$ & 0,728 \\
\hline SE3 & $<---$ & F1 & 1,012 & 0,870 & 0,030 & 33,346 & $\mathrm{p}<0,001$ & 0,722 \\
\hline SE2 & $<---$ & F1 & 0,997 & 0,857 & 0,035 & 28,737 & $\mathrm{p}<0,001$ & 0,780 \\
\hline SE1 & $<---$ & F1 & 0,769 & 0,735 & 0,030 & 25,324 & $\mathrm{p}<0,001$ & 0,772 \\
\hline SE6 & $<---$ & F2 & 1,000 & 0,816 & & & & 0,605 \\
\hline SE7 & $<---$ & F2 & 1,055 & 0,861 & 0,034 & 30,838 & $\mathrm{p}<0,001$ & 0,742 \\
\hline SE8 & $<---$ & F2 & 1,089 & 0,778 & 0,041 & 26,550 & $\mathrm{p}<0,001$ & 0,666 \\
\hline SE9 & $<---$ & F2 & 1,119 & 0,879 & 0,035 & 31,818 & $\mathrm{p}<0,001$ & 0,540 \\
\hline SE10 & $<---$ & F2 & 1,089 & 0,883 & 0,034 & 32,066 & $\mathrm{p}<0,001$ & 0,735 \\
\hline SE11 & $<---$ & F3 & 1,000 & 0,850 & & & & 0,757 \\
\hline SE12 & $<---$ & F3 & 0,956 & 0,853 & 0,032 & 29,862 & $\mathrm{p}<0,001$ & 0,630 \\
\hline SE13 & $<---$ & F3 & 0,860 & 0,718 & 0,036 & 23,609 & $\mathrm{p}<0,001$ & 0,742 \\
\hline
\end{tabular}

Standardize edilmiş katsayılar incelendiğinde faktör yüklerinin yüksek, standart hata değerlerinin düşük, $\mathbf{t}$ değerlerinin anlamlı $(\mathrm{p}<0,001), \boldsymbol{R}^{2}$ değerlerinin yüksek olduğu belirlenmiştir. Bu sonuçlar önceden belirlenen faktör yapısına ilişkin yapı geçerliliğini doğrulamaktadır.

\section{Sosyal Etkileşim Ölçeği Güvenirlik Katsayıları ve Madde Analizi}

Saha araştırması sonucunda sosyal etkileşim ölçeğinin güvenirliğini belirlemek üzere iç tutarlılık katsayıları (Cronbach Alpha) hesaplanarak aşağıda Tablo 5'te verilmektedir. 
Tablo 5. Sosyal Etkileşim Ölçeği Güvenirlik Katsayıları

\begin{tabular}{|c|c|c|}
\hline & & Alpha \\
\hline \multirow{3}{*}{$\begin{array}{l}\text { Sosyal Etkileşim } \\
\text { Boyutları }\end{array}$} & Yakın Etkileşim & 0,922 \\
\hline & $\begin{array}{l}\text { Turizm Çekicilikleri ve Destek Hizmetlerinde Gerçekleşen } \\
\text { Etkileşim }\end{array}$ & 0,945 \\
\hline & Resmi (Formel) Etkileşim & 0,918 \\
\hline \multicolumn{2}{|l|}{ Sosyal Etkileşim } & 0,954 \\
\hline
\end{tabular}

Ölçeğin güvenilir olduğu saptanmıştır. Ölçek puanı ve alt boyutların puanları hesaplanırken aritmetik ortalama kullanılmıştır.

Tablo 6. Sosyal Etkileşim Ölçeği Madde Analizi

\begin{tabular}{|l|c|c|c|c|}
\hline & $\begin{array}{c}\text { Madde } \\
\text { Silindiğinde } \\
\text { Ölçek Puanı }\end{array}$ & $\begin{array}{c}\text { Madde } \\
\text { Silindiğinde } \\
\text { Varyans }\end{array}$ & $\begin{array}{c}\text { Madde Toplam } \\
\text { Korelasyonu }\end{array}$ & $\begin{array}{c}\text { Madde Silindiğinde } \\
\text { Cronbach Alpha }\end{array}$ \\
\hline SE1 & 47,662 & 109,537 &, 687 &, 949 \\
\hline SE2 & 47,851 & 106,353 &, 751 &, 947 \\
\hline SE3 & 47,872 & 105,991 &, 770 &, 947 \\
\hline SE4 & 47,853 & 107,107 &, 735 &, 948 \\
\hline SE5 & 47,839 & 105,311 &, 804 &, 946 \\
\hline SE6 & 47,755 & 107,434 &, 779 &, 946 \\
\hline SE7 & 47,748 & 106,707 &, 816 &, 945 \\
\hline SE8 & 47,967 & 106,242 &, 721 &, 945 \\
\hline SE9 & 47,722 & 106,130 &, 810 &, 945 \\
\hline SE10 & 47,681 & 106,418 &, 825 &, 948 \\
\hline SE11 & 47,754 & 107,620 &, 723 &, 949 \\
\hline SE12 & 47,647 & 108,663 &, 713 &, 671 \\
\hline SE13 & 47,790 & 108,435 & & \\
\hline
\end{tabular}

Madde analizi sonucunda ölçek maddelerine ilişkin madde toplam korelasyon değerlerinin çok yüksek (>0.30) olduğu saptanmıştır. Genel güvenirlik ve madde analizleri sonuçlarına göre ölçek maddelerinin tutarlılık gösterdiği ve ölçeğe olan katkılarının yüksek olduğu saptanmıştır.

Araştırmanın varsayımları şu şekildedir: Yerleşik yabancı ve yerel halk arasında bir etkileşim durumunun var olması, turizm destinasyonunu ziyaret eden turist ile aynı kökenden olan yerleşik yabancının, turist-yerel halk uyumsuzlukları, anlaşmazlıkları ve çatışma durumlarına ikamet süresi uzun olduğu için, derinlemesine inceleme olanağı yaratacağı, araştırmada; örneklemin evreni temsil ettiği, ulaşılabilen katılımcıların, yerleşik yabancıları temsil ettikleri, veri toplama araçlarını ölçmek istenilen kavramları ölçtükleri, veri analiz yöntemlerinin hipotezlerin test edilmesinde yeterli oldukları, katılımcıların veri toplama aracina samimi ve dürüst yanıt verdikleri varsayılmaktadır. Araştırmanın sınırlılıklarını; kullanılan veri toplama aracı, evren ve örneklem (Marmaris ilçesinde ulaşılabilen yerleşik yabancı) oluşturmaktadır.

\section{BULGULAR}

Aşağıda yerleşik yabancların tanımlayıcı özelliklerini içeren bulgular Tablo 7'de sunulmuştur. 
Yaş değişkenine göre; yerleşik yabancıların \%17,5'inin 65 yaş üzeri, \%28,5'inin 50-64 yaş ve $\% 53,9$ 'unun 49 yaş altı olması dikkat çekicidir. Birleşik Krallıkta devlet emeklik yaşı, doğum yılına göre değişme şartıyla, kadın ya da erkek olmak fark etmeksizin 60 ile 68 yaş aralığındadır (www.turkcetax.com). Mevcut bulgu Marmaris destinasyonunu yerleşmek için tercih eden Birleşik Krallık kökenli yabancıların sadece emeklilerden oluşmadığını, farklı yaş grupları ile yaşam biçimi göçü kapsamında geldiklerini göstermekte ve literatürü desteklemektedir (Benson ve O'Reilly, 2016:26-27; Benson ve O'Reilly, 2009:2).

Cinsiyet değişkenine göre katılımcıların \%57,9'u kadınlardan oluşmaktadır. Yerleşik yabancılarda cinsiyetin kadın olma durumundaki yüksek oran, Türkiye' de yapılmış diğer akademik çalışmaları desteklemektedir. Özgüneş (2017) Muğla/Bodrum'da gerçekleştirdiği saha çalışmasında anketi cevaplandıran toplam 255 yerleşik yabancının \%73,3'ünü; Yazan ve arkadaşları (2017) Antalya/Alanya'da yürüttüğü saha çalışmasında 200 yerleşik yabancı katılımcıdan \%59'unu; Şirin (2017) Antalya/Alanya'daki araştırmasında 317 yerleşik yabancı katılımcıdan \%61'ini; Yirik ve arkadaşları (2015) Antalya'daki yerleşik yabancıların sosyo-kültürel algılarına ilişkin çalışmalarında 428 yerleşik yabancı katılımcının \%64,5'ini kadınların oluşturduğunu belirtmişlerdir. Yerleşik yabancılar içerisinde kadınların evlilik, çalışma, daha iyi bir yaşam için erkeklere göre başka bir ülkeye yerleşmede daha cesur ve atılımcı oldukça söylenebilir.

Tablo 7. Tanımlayıcı Özelliklerin Yerleşik Yabancılara Göre Dağılımı

\begin{tabular}{|c|c|c|c|c|c|c|c|}
\hline \multicolumn{2}{|c|}{ Tanımlayıcı Özellik } & \multirow{2}{*}{$\frac{\mathbf{n}}{114}$} & \multirow{2}{*}{$\begin{array}{c}\% \\
\% 29,8\end{array}$} & \multicolumn{2}{|c|}{ Tanımlayıcı Özellik } & \multirow{3}{*}{$\frac{\mathbf{n}}{146}$} & \multirow{2}{*}{$\begin{array}{c}\% \\
\% 38,2\end{array}$} \\
\hline \multirow{4}{*}{$\stackrel{\mathscr{\tau}}{\overparen{\gamma}}$} & 35 Yaş Altı & & & \multirow{4}{*}{ 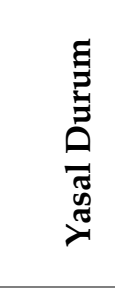 } & \multirow[t]{2}{*}{ Oturma İzni } & & \\
\hline & $36-49$ & 92 & $\% 24,1$ & & & & \\
\hline & $50-64$ & 109 & $\% 28,5$ & & $\begin{array}{l}\text { Çifte } \\
\text { Vatandaş }\end{array}$ & 174 & $\% 45,5$ \\
\hline & $\begin{array}{l}65 \text { Yaş ve } \\
\text { Üzeri }\end{array}$ & 67 & $\% 17,5$ & & $\begin{array}{l}\text { Turist } \\
\text { Vizesi }\end{array}$ & 62 & $\% 16,2$ \\
\hline \multirow{2}{*}{ 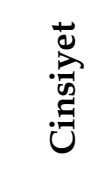 } & Kadın & 221 & $\% 57,9$ & \multirow{4}{*}{ 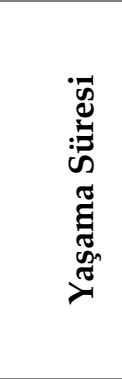 } & 1 Yıldan Az & 45 & $\% 11,8$ \\
\hline & Erkek & 161 & $\% 42,1$ & & 1-5 Y1l & 89 & $\% 23,3$ \\
\hline \multirow{4}{*}{ 蛋 } & $\begin{array}{l}\text { Temel } \\
\text { Eğitim }\end{array}$ & 135 & $\% 35,3$ & & 6-10 Yil & 114 & $\% 29,8$ \\
\hline & Üniversite & 147 & $\% 38,5$ & & $\begin{array}{l}11 \quad \text { Yll ve } \\
\text { Üzeri }\end{array}$ & 134 & $\% 35,1$ \\
\hline & Lisansüstü & 30 & $\% 7,9$ & \multirow{3}{*}{ 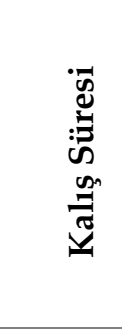 } & 7-9 Ay & 65 & $\% 17,0$ \\
\hline & Diğer & 70 & $\% 18,3$ & & $\begin{array}{l}10-12 \text { Ay } \\
\text { Aralığında }\end{array}$ & 88 & $\% 23,0$ \\
\hline \multirow{6}{*}{ 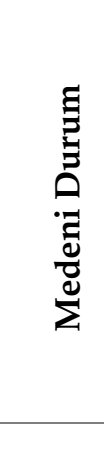 } & Bekâr & 114 & $\% 29,8$ & & $\begin{array}{l}\text { Uzun } \\
\text { Süredir } \\
\text { (Y1lın } \\
\text { Tamamı) }\end{array}$ & 229 & $\% 59,9$ \\
\hline & Eşi Ölmüş & 25 & $\% 6,5$ & \multirow{5}{*}{ 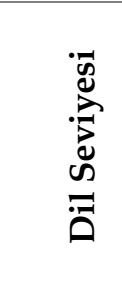 } & Bilmiyorum & 58 & $\% 15,2$ \\
\hline & Boşanmış & 29 & $\% 7,6$ & & Temel & 127 & $\% 33,2$ \\
\hline & $\begin{array}{l}\text { Birlikte } \\
\text { Yaşıyor }\end{array}$ & 35 & $\% 9,2$ & & Orta & 84 & $\% 22,0$ \\
\hline & Evli & 179 & $\% 46,9$ & & İyi & 62 & $\% 16,2$ \\
\hline & & & & & Çok İyi & 51 & $\% 13,4$ \\
\hline
\end{tabular}


Çalışmada yerleşik yabancıların eğitim durumu değişkenine göre $\% 46,4^{\prime}$ ü lisans ve üstü eğitim sahibidir. Yerleşik yabancılara yönelik Türkiye'de yapılan çalışmalarda yerleşik yabancıların eğitim durumu lisans ve lisansüstü olanların oranları; Çil (2013)'in çalışmasında yerleşik yabancı katılımcıların \%46,1; Yirik ve arkadaşları (2015)'nin çalışmalarında yerleşik yabancı katılımcıların $\% 47,6$ 'sıdır. Bu bağlamda eğitim düzeyi yüksek yabancıların bir kısmının Türkiye'nin kıyı bölgelerini yerleşim yeri olarak seçtikleri ve turizm destinasyonlarına sosyal sermayeleri ile zenginlik kattıkları söylenebilir.

Medeni durum değişkenine göre; yerleşik yabancıların \%56,1'i satın aldıkları ya da kiraladıkları evde en az iki kişi yaşamaktadır. Marmaris destinasyonundaki yerleşik yabancı çiftlerin bir kısmı evli olarak, bir kısmı ise birlikte oldukları kişi ile aynı evi paylaşmaktadır.

Yasal durum değişkenine göre yerleşik yabancıların \%45,5'i çifte vatandaştır. Birleşik Krallık vatandaşlığı yanı sıra T.C. vatandaşlı̆̆ını sonradan alan yerleşik yabancılar; 5 yıl kesintisiz Türkiye'de ikamet etme, Türkiye'ye yerleşmeye karar verdiğini destekleyen davranışlarda bulunma (örneğin; Türkiye'de gayrimenkul satın alma, iş kurma veya yatırım yapma, işyerini Türkiye'ye taşıma, çalışma izni ile Türkiye' de bir işyerinde çalışma, Türk vatandaşı ile 3 yıllık evli olma ve benzeri) şartlarından bir ya da birkaçını gerçekleştirmiş yabancılardır (www.ingilizkonsoloslugu.org). Katılımcı yerleşik yabancıların \%38,2'si oturma iznine sahip, $\% 16,2$ 'si ise turist vizesi ile Marmaris destinasyonunda yasal olarak bulunmaktadir.

Yaşama süresi değişkenine göre yerleşik yabancıların; \%35,1'i 11 yıl ve üzeri süredir, \%29,8'i 610 yıl aralığını kapsayan süredir, bir diğer ifade ile \%64,9'u 6 yıl ve üzeri süredir Marmaris destinasyonunda yaşamaktadır. Marmaris destinasyonunda yerleşik yabancıların yaklaşık \%65'inin yıllardır aynı mekânı ve atmosferi yerel halk ile paylaşmaları, 6 yıl ve üzerinde bir süredir birlikte gündelik yaşamı paylaşmaları anlamı taşımaktadır.

Kalış süresi değişkenine göre katılımcı yerleşik yabancıların \%59,9'u Marmaris'e sürekli olarak yerleşmişler, yılın tamamını Marmaris'te geçirmektedirler. \%23'ü 10 aydan fazla, 1 yıldan az süre Marmaris'te bulunmakta, turistik amaçlı yurt içi ve/veya yurt dışı seyahatler ya da kısa süreli köken ülkeye gidiş-dönüşleri söz konusu olmaktadır. Yerleşik yabancıların \%17'si ise 7-9 ay arası Marmaris'te kalmakta, daha çok turist vizesi ile Marmaris'te bulunan giriş-çıkış yapan yabancılardan oluşmaktadır. Yerleşik yabancıların $\% 82,9^{\prime}$ u yıl içerisinde 10 ay ve üzerinde bir süre Marmaris'te bulunmaktadır.

Dil değişkenine göre yerleşik yabancıların $\% 33,2$ 'si temel düzeyde, $\% 22$ 'si orta düzeyde, $\% 16,2$ 'si iyi, \%13,4'ü çok iyi düzeyde Türkçe bilmekte, gündelik yaşamlarındaki gereksinimlerini karşılamak için kendilerini ifade etmeye çalışmaktadırlar. Katılımcıların \%15,2'si hiç Türkçe bilmemekte, turizmin en önemli ekonomik faaliyet alanı olduğu Marmaris'te İngilizce bilen yerel halk, turizm çalışanları ve çeşitli hizmet sağlayıcılar İngilizce konuşarak, Türkçe bilmemeyi yerleşik yabancı açısından bir sorun olmaktan çıkartmaktadır.

Marmaris destinasyonunda, turist ile aynı kökenden olan, yerleşik yabancıların sosyal etkileşim ve temastan duyulan memnuniyete ilişkin tek örnek t-testi sonuçları aşağıda Tablo 8 'de yer almaktadir. 
Tablo 8. Yerleşik Yabancı Sosyal Etkileşim ve Temastan Duyulan Memnuniyet Tek Örnek T-Testi Sonuçları

\begin{tabular}{|l|c|c|c|c|c|c|}
\hline & N & Ortalama & $\begin{array}{c}\text { Std. } \\
\text { Sapma }\end{array}$ & $\mathbf{t}$ & $\mathbf{p}$ & Fark \\
\hline Yakın Etkileşim & 382 & 3,907 & 0,850 & 20,873 & 0,000 & 0,907 \\
\hline $\begin{array}{l}\text { Turizm Çekicilikleri ve Destek Hizmetlerinde } \\
\text { Gerçekleşen Etkileşim }\end{array}$ & 382 & 4,000 & 0,805 & 24,276 & 0,000 & 1,000 \\
\hline Resmi (Formel) Etkileşim & 382 & 3,963 & 0,804 & 23,397 & 0,000 & 0,963 \\
\hline Sosyal Etkileşim & 382 & 3,949 & 0,739 & 25,095 & 0,000 & 0,949 \\
\hline Temastan Duyulan Memnuniyet & 382 & 4,183 & 0,825 & 28,040 & 0,000 & 1,183 \\
\hline Tek Örneklem T-Testi (Test Değeri=3) & & & & & \\
\hline
\end{tabular}

Çalışmada sosyal etkileşim ve temastan duyulan memnuniyet tek örnek t-testi analizi yapılırken, 5 'li Likerte göre orta değer ${ }^{1}$ olan " 3 sayısı" 2 , eşik değer, bir başka ifadeyle test değeri olarak belirlenmiş ve Tablo $8^{\prime}$ de yerleşik yabancılara ait söz konusu t-testi sonuçları verilmiştir. Yerleşik yabancilarda sosyal etkileşim ve temastan duyulan memnuniyet puanlarının orta/eşik değer olan $3^{\prime}$ ten yüksek olduğu saptanmıştır $(\mathrm{p}<0,05)$. Yerleşik yabancilarda; sosyal etkileşim ve sosyal etkileşim alt boyutlarının ortalama puanları, belirlenen orta/eşik değere göre incelendiğinde, yakın etkileşim (fark=0,907), turizm çekicilikleri ve destek hizmetlerinde gerçekleşen etkileşim (fark=1,000), resmi (formel) etkileşim (fark $=0,963$ ) ve sosyal etkileşim (fark=0,949) 3'ten yüksek bulunmuştur. Sosyal etkileşim boyutları içerisinde, turizm çekicilikleri ve destek hizmetlerinde gerçekleşen etkileşim boyutunun puanları en yüksek farka sahiptir. Marmaris destinasyonunda turizm gelişimine paralel olarak çok sayıda turizm işletmesinin varlığı, spordan sanata birçok alanda gerçekleştirilen etkinlikler, doğal ve yapılı fiziki çevrenin sunduğu imkânlar, yerleşik yabancıların yerel halk ile resmi olmayan (informel) etkileşimleri için çok sayıda ortam yaratmaktadır. Söz konusu karşılaşma ve temas ortamları, Marmaris destinasyonunun sahip olduğu özellikler, yerleşik yabancıların yerel halk ile yakın, samimi ilişkiler kurmalarında, sunduğu atmosfer ile yüksek düzeyde bir etki yarattı̆̆ düşünülmektedir. Sosyal etkileşim ile bağlantılı olarak sorulan temastan duyulan memnuniyetin ortalama puanı da (fark=1,183) orta/eşik değer olarak belirlenen 3'ten büyük bulunmuştur. Yerleşik yabancıların yerel halk ile sosyal etkileşimi ve temastan duyduğu memnuniyet düzeyi belirlenen eşik değerin üzerinde olduğundan, yerel halkla ilişki ve etkileşimlerinin beklentilerini karşıladığı, yerel halk ile olumlu ilişkiler yaşadıkları, ilişkilerinden tatmin oldukları ve son derece uyumlu ilişkiler yaşadıkları söylenebilir.

Aşağıda Tablo 9'da yerleşik yabancıların sosyal etkileşim puanlarının kalış süresi değişkenine göre farklılaşma durumunu gösteren bulgulara yer verilmiştir.

\footnotetext{
${ }^{1}$ Orta değer: Sayısal veri serisi küçükten büyüğe sıralandığında, serinin ortasında kalan sayıdır.

2 5'li Likert veri serisi, 1'den başlayarak 5'e kadar kodlanmaktadır. En olumsuz cevap, en düşük puan olan (1), en olumlu cevap, en yüksek puan olan (5) sayısı ile temsil edilmektedir. 5'li Likertte, 3 sayısı orta değeri göstermektedir. Çalışmada orta değer olan 3, eşik değer olarak kabul edilmiştir.
} 
Tablo 9.Yerleşik Yabancılarda Sosyal Etkileşim Puanlarının Kalış Süresine Göre Farklılaşma Durumu

\begin{tabular}{|c|c|c|c|c|c|c|}
\hline & Grup & $\mathrm{N}$ & Ort & Ss & $\mathrm{F}$ & $\mathrm{p}$ \\
\hline \multirow{3}{*}{ Yakın Etkileşim } & 7-9 Ay & 65 & 4,025 & 0,766 & \multirow{3}{*}{2,573} & \multirow{3}{*}{0,078} \\
\hline & 10-12 Ay Aralığında & 88 & 4,030 & 0,773 & & \\
\hline & $\begin{array}{l}\text { Uzun Süredir (Yllın } \\
\text { Tamamı) }\end{array}$ & 229 & 3,827 & 0,893 & & \\
\hline \multirow{3}{*}{$\begin{array}{l}\text { Turizm Çekicilikleri ve Destek } \\
\text { Hizmetlerinde Gerçekleşen Etkileşim }\end{array}$} & 7-9 Ay & 65 & 3,991 & 0,876 & \multirow{3}{*}{0,222} & \multirow{3}{*}{0,801} \\
\hline & 10-12 Ay Aralığında & 88 & 4,050 & 0,813 & & \\
\hline & $\begin{array}{l}\text { Uzun Süredir } \quad(\text { Yllın } \\
\text { Tamamı) }\end{array}$ & 229 & 3,983 & 0,784 & & \\
\hline \multirow[b]{3}{*}{ Resmi (Formel) Etkileşim } & 7-9 Ay & 65 & 3,850 & 0,875 & \multirow{3}{*}{0,780} & \multirow{3}{*}{0,459} \\
\hline & 10-12 Ay Aralığında & 88 & 3,974 & 0,773 & & \\
\hline & $\begin{array}{l}\text { Uzun Süredir } \quad\left(Y_{1} l ı n\right. \\
\text { Tamamı) }\end{array}$ & 229 & 3,990 & 0,796 & & \\
\hline \multirow{3}{*}{ Sosyal Etkileşim } & 7-9 Аy & 65 & 3,953 & 0,784 & \multirow{3}{*}{0,603} & \multirow{3}{*}{0,548} \\
\hline & 10-12 Ay & 88 & 4,022 & 0,731 & & \\
\hline & $\begin{array}{l}\text { Uzun Süredir (Yılın } \\
\text { Tamamı) }\end{array}$ & 229 & 3,920 & 0,731 & & \\
\hline
\end{tabular}

Yerleşik yabancıların yakın etkileşim puanları kalış süresi değişkenine göre anlamlı farklılık göstermemektedir ( $p>0.05)$. Yerleşik yabancıların yerel halk ile yakın etkileşimi; yüz yüze iletişim içerisine girerek, paylaşımda bulunarak, hediyeleşerek, evlerinde misafir olarak yerel halkı ağırlayarak ve yerel halk ile beraber ortak aktiviteler yaparak gerçekleşmektedir. Herhangi bir kurala bağlı olmayan, samimiyet ve sevgi duygusunun hâkim olduğu yakın etkileşim Marmaris toplumunda yerleşik yabancı-yerel halk ilişkisinin boyutlarını göstermektedir. Bu bağlamda, yerleşik yabancıların kalış süresi değişkenine göre farklılık göstermeksizin; biz duygusu taşıdıkları, benzer yaşam biçimine sahip oldukları, Marmaris toplumuna uyum sağladıkları, bütünleştikleri, dayanışma içerisinde oldukları çıkarımlarının yapılabileceği düşünülmektedir.

Yerleşik yabancıların turizm çekicilikleri ve destek hizmetlerinde gerçekleşen etkileşim puanları kalış süresi değişkenine göre anlamlı farklılık göstermemektedir ( $>00.05)$. Marmaris destinasyonu sahip olduğu; bükleri, koyları, modern yat limanları, uluslararası standartlara sahip tesisleri, antik kentlere yakınlığı, yeşil ve mavinin iç içe geçtiği eşsiz manzaraları, eğlence ve renkli gece yaşamı ile dikkat çekmektedir. Kıyı şeridi boyunca uzanan konaklama, yiyecekiçecek, eğlence işletmeleri ile yat ve kurvaziyer limanları her yıl çok sayıda yerli ve yabancı turisti bölgeye çekmekte, söz konusu çekicilikler, yerel halk ve yerleşik yabancilar için sosyalleşme, temas ve etkileşim fırsatları sunmaktadır. Destinasyonda gerek turizme bağımlı olarak ortaya çıkan işletmeler (eğlence, yiyecek-içecek, hatıra-hediyelik eşya, ulaştırma, seyahat ve rekreasyon işletmeleri), gerekse turizmden bağımsız olarak yerelin gereksinimlerine cevap vermek için faaliyet gösteren işletmelerde, sahil gibi kamusal açık alanlarda etkileşim gerçekleşmektedir. 
Yerleşik yabancıların yerel halk ile jest, mimik ve duruşları ile gerçekleştirdikleri-, bir başka ifade ile odaklanmamış etkileşimleri, çoklu karşılaşma ve temasları ile yabancıllı̆̆ ortadan kaldırmakta ve birbirlerine aşina oldukları, diğerini/ötekini kendisi gibi görmeye başladıkları söylenebilir.

Yerleşik yabancıların resmi (formel) etkileşim puanları kalış süresi değişkenine göre anlamlı farklılık göstermemektedir ( $>0.05)$. Yerleşik yabancıların yerel halk ile belirli bir kurala bağlı olarak, profesyonel ilişkilerden kaynaklanan sosyal etkileşimleridir. Yerleşik yabancıların; işyerinde, ürün ya da hizmet sunarken/alırken ve kamu kurum ve kuruluşları, resmi daireler, belediye vb. hakkında bilgi alışverişinde bulunurken yerel halk ile etkileşimlerinin, kalış süresi değişkenine farklılık göstermemesi, Marmaris destinasyonunda sosyal kurallara ve rollerine uygun sosyal davranışları gerçekleştirmeyi öğrendikleri biçiminde yorumlanabilir.

Turistlerin kısa süreli kalışlarında genel eğilimleri; merkezi yerlerde kalma ve sadece önemli, görülmesi gereken yerleri ziyaret etme biçiminde gerçekleşmektedir. Turistlerin daha uzun süreli kalışlarında ise kısa süreli kalan turistlere kıyasla daha fazla cazibe merkezini ziyaret etme, destinasyon çevresini etraflıca keşfetme ve daha fazla sosyal, kültürel, ekonomik ve çevresel etkiler yaratmaları söz konusu olmaktadır (Barros ve Machado, 2010:693). Turistlerin kalış süresinin artması, özellikle kitle turistlerinin çevresel bir balon olarak onlar için yaratılmış destinasyonun ön bölgelerinden, gündelik yaşamın akıp gittiği arka bölgelere geçiş için zamansal açıdan fırsat ve yerel halkla temas imkânı yaratmaktadır. Bireysel ve bağımsız olarak seyahat eden turistlerin yerel halkla teması ve etkileşiminin, dil engeli yaşamadıkları ve yerel halkın kültürel mesafesinin kısa olduğu durumlarda gerçekleşmesinin beklenebileceği söylenebilir. Ancak turist turizm destinasyonunda ister kısa, isterse uzun süreli kalsın yine de yerel halkla sosyal ilişki ve etkileşimlerini gözlemleyebilmek, çatışma ya da uyumsuzluklarını analiz edebilmek için çok yönlü araştırmalar yapılarak söz konusu boşluğun doldurulması gerekmektedir.

\section{TARTIŞMA, SONUÇ VE ÖNERILER}

Çalışmadan elde edilen bulgular; Marmaris destinasyonunda yerleşik yabanc1-yerel halk ilişkisinin olumlu, kaliteli, samimi bir biçimde gerçekleştĭgini, aralarındaki etkileşimi yüksek düzeyde önemsediklerini ve birbirleriyle olan temaslarından yüksek düzeyde memnun olduklarını göstermektedir. Yerleşik yabancıların yakın etkileşim, turizm çekicilikleri ve destek hizmetlerinde gerçekleşen etkileşim, resmi (formel) etkileşim, sosyal etkileşim puanları kalış süresi değişkenine göre anlamlı farklılık göstermemektedir.

Turist-yerel halk ilişkisinde turistin destinasyonda kısa süre kalması; yerel halk ile ilişkilerinin geçici olmasına, yüzeysel ilişkiler kurmasına, anında doyuma odaklanmış ilişkiler yaşamasına, genellikle bir plan dahilinde hareket ettiği için zamansal ve mekânsal olarak kısıtlı olmasına, ziyaretçisi olduğu topluma karşı sahip olduğu kültürel mesafesinin etkisinde, yabancılık duygusu içerisinde, sömürüye açık biçimde, maddiyata dayalı, eşit ve dengeli olmayan bir deneyim yaşayarak, turist rolünü oynayarak ilişkilerini yürütmesine sebep olmaktadır. Bu bağlamda turistyerel halk ilişkisinde tarafların birbirlerine yönelik davranışlarında kötü davranmamak için çaba harcamaya gerek duymamaları olağandır. Oysa turist ile aynı kökenden olan yerleşik yabancı destinasyonda turiste göre kalıcıdır, 6 ay ve üzerinde bir süre yerel halk ile gündelik yaşamı paylaşmaktadır. Dolayısıyla yerleşik yabancının kalış süresinin uzunluğu; yerel halk ile kalıcı ve derinlemesine ilişkiler kurması, zamana yayılı bir doyum, zamansal ve mekânsal kısıtlamalardan uzak, kültürel ve sosyal mesafesinin azaldığı, bir diğer ifadeyle yakınlaşmalarının arttığı, tanıdık ve aşina olunan kişiler ile hile ve aldatmacadan uzak, maneviyata (sevgi, saygı, hoşgörü, yardımlaşma ve benzeri) dayalı, eşit ve dengeli bir deneyim yaşamasını sağlamaktadır. Yerleşik yabancı yerel halkı komşusu olarak benimsemekte, eve yemeğe çağırma veya yardıma ihtiyaç 
duyması durumunda çaba sarf etmeye gerek duymaktadır. Yerleşik yabancılar yerel halk ile temaslarından memnuniyet duymakta, yakın etkileşim, turizm çekicilikleri ve destek hizmetlerinde etkileşim, resmi (formel) etkileşim biçimlerine yüksek düzeyde önem vermektedir. Yakın sosyal ilişkiler, karşılıklı yakın etkileşim, tarafların birbirlerine zaman ayırması, değer ve emek vermesi, sevgi ile oluşmaktadır. Yerleşik yabancının mahrem alanı olan evini yerel halktan arkadaşlarına açması, sosyal etkinliklerde yerel halk ile sosyal ilişkiler kurmaya, iletişim içerisinde bulunmaya önem vermesi, yerel halka iyi davranma ve iyi geçinme çabası içerisinde olduğunu göstermektedir.

Elde edilen bulgulara göre; kalış süresi daha uzun olan turistlerin temsili olan yerleşik yabancıların; kalış sürelerinin uzunluğunun, sosyal ilişki ve etkileşimlerinin olumlu olmasında bir etkiye sahip olmadığı tespit edilmiştir. Söz konusu bu durum turist-yerel halk ilişkisinin niteliğinin belirlenmesinde, kalış süresinin bir etkisinin olmadığını tescillemektedir. Bu bağlamda, turizm destinasyonlarında turist-yerel halk uyumsuzluk ve anlaşmazlıklarına yol açan nedenler arasında, turistin destinasyonda kısa süre kalması, bir başka ifadeyle geçici olması durumu dışında kalan, kültürel farklılıkların etkili faktör olduğu sonucuna varılmıştır.

Turist ile aynı kökenden olan yerleşik yabancı ve yerel halk arasındaki etkileşim, çalışma kapsaminda Marmaris destinasyonunda hem bugünkü durumu analiz edebilme hem de gelecekte yaşanması muhtemel durumları bugünden görebilme imkânı sunmuştur. Bu bağlam da geliştirilen öneriler şu şekildedir:

- Turizm destinasyonunda genişletilmiş yerellik vizyonu ile yerelde gömülü olan, turistyerleşik yabanci-yerel halk ilişkileri ile yeniden üretilen, öğrenilmesi fiziksel ve sosyal yakınlık gerektiren bilginin, rekabet avantajı sağlayan bir üstünlük olarak, yerel yönetimler tarafından ortaya çıkartılması, tüm turizm paydaşları için bir değere dönüştürülmesi gerekmektedir.

- Yerleşik yabancı ve turistlerden elde edilen bilgi, ilişki sermayesi, insan sermayesi, sosyal sermaye gibi unsurlardan oluşan entelektüel sermayenin yerelde zenginleşmesini sağlayacak, karşılıklı etkileşime imkân veren ortamların arttırılması gerekmektedir.

- Turist-turizm çalışanı, turist-turist, turist-yerel halk ilişki ve etkileşimlerinin, turistin tatil deneyiminden tatmin duyması ve tekrar ziyaret etme niyeti üzerindeki etkisi göz önünde bulundurulmalıdır. Bu bağlamda turizm işletmelerinin; kültürel farklılıkları göz önünde bulundurarak, kültürel iletişimin geliştirilmesi ve yanlış anlaşılmaların önüne geçilmesi için çalışanlarına ve turistlerin öğrenme süreçlerine katkı sağlaması gerekmektedir.

- Çalışanların farklı kültürler ile iletişim kurma becerilerini artıracak hizmet içi eğitimler verilmelidir.

- Turistlerin kültürel özelliklerine uygun olarak geliştirilen, istek ve beklentilerine cevap veren turistik ürünler oluşturulurken, örneğin koy ya da plajların yerel halka kapatılması gibi durumlardan, kaynak kullanımından dolayı ortaya çıkabilecek çıkar çatışmalarına yol açılmamalıdır.

- Farklı kültürlerin karşılaşmalarında dil bilmemek, sosyal ilişki ve etkileşimlerde en büyük engellerden biridir. Türkiye'nin dünyaya açlan pencerelerinden olan Marmaris'te, yabancı dil öğrenmeyi, yerel halk kişisel gelişiminin bir parçası ve dünya vatandaşlığının vizesi olarak görmelidir.

- Kreş ve anaokullarından başlayarak, kültürlerarası ilişkiler konusunda eğitimler verilmelidir.

- Üniversitelerde bölüm veya program ayırt etmeksizin, farklı kültürler ile iletişim ve ilişki kurma becerisini artıracak dersler müfredata alınmalıdır. 
- Turizme yönelik meslek edindirme ve mesleki gelişim kurslarında; turist-turizm çalışanı ve turizm çalışanları arası ilişkiler ile iletişim dersleri, uygulamalı, proje tabanlı gerçekleştirilmelidir.

\section{KAYNAKÇA}

Avcıkurt, C. (2007). Turizm Sosyolojisi: Turist-Yerel Halk Etkileşimi (2. Basım). Ankara: Detay Yayıncilik.

Bahar, H. İ. (2009). Sosyoloji (3. Basım). Ankara: USAK Yayınları.

Barros, C., P., and Machado, L. P. (2010). The Length of Stay in Tourism. Annals of Tourism Research, 37(3), 692-706.

Benson, M. and O'Reilly, K. (2009). Migration and The Search for A Better Way of Life: A Critical Exploration of Lifestyle Migration. The Sociological Review, 57(4), 608-625.

Benson, M. and O'Reilly, K. (2016). From Lifestyle Migration to Lifestyle in Migration: Categories, Concepts and Ways of Thinking. Migration Studies, 4(1), 20-37.

Bimonte, S., and Punzo, L. F. (2016). Tourist Development and Host-Guest Interaction. Annals of Tourism Research (58), 128-139.

Capistrano, R.; Weaver, A. (2017). Host-Guest Interactions between First-Generation Immigrants and Their Visiting Relatives: Social Exchange, Relations of Care and Travel. International Journal of Culture, Tourism and Hospitality Research, 11(3), 403-420.

Carneiro, M. J., and Eusébio, C. (2015). Host-Tourist Interaction and Impact of Tourism on Residents' Quality of Life. Tourism \& Management Studies, 11(1), 25-34.

Carneiro, M. J., Eusébio, C., and Caldeira, A. (2018). The Influence of Social Contact in Residents' Perceptions of the Tourism Impact on Their Quality of Life: A Structural Equation Model. Journal of Quality Assurance in Hospitality \& Tourism, 19(1), 1-30.

Çil, K. (2013). Yerleşik Yabancıların Türkiye Alggılamaları: Antalya Örneği. Yayınlanmamış Yüksek Lisans Tezi, Akdeniz Üniversitesi, Antalya.

Demir Özcan, N. (2017). Bireylerin Tüketim Nesnesine Dönüşmesinde Sosyal Medyanın Etkisi. Sosyoloji Konferansları No: 55 (2017-1)/(s. 277-288). İstanbul, İstanbul Üniversitesi Yayınları.

Ergil, D. (1984). Toplumsal Örgütlenmenin Yapısı. Ankara Üniversitesi Sosyal Bilimler Fakültesi Dergisi, 39(1), 15-31.

Goffman, E. (2017). Etkileşim Ritüelleri Yüzyüze Davranış Üzerine Denemeler. (Çeviren, A. Bölükbaşı) Ankara, Heretik Yayınları:46-Goffman Dizisi:4.

Göç Politika ve Projeleri Daire Başkanlığı. (2016). İçişleri Bakanlığı Göç İdaresi Genel Müdürlüğü. Marmaris İlçesinde İkametli Olarak Bulunan Yabancıların Dağılımı. Ankara.

Göker, G. (2013). Göç, Kimlik, Aidiyet: Kültürlerarası İletişim Açısından İsveçli Türkler, Yayınlanmamış Doktora Tezi, Fırat Üniversitesi, Elazı̆g.

Güney, S. (2016). Davranış Bilimleri (10. Basım). Ankara: Nobel Yayıncılık.

Hooper, D., Coughlan, J., and Mullen, M. R. (2008). Structural Equation Modelling: Guidelines for Determining Model Fit. The Electronic Journal of Business Research Methods, 6(1), 53-60.

https://turkcetax.com/ingiltere-devlet-emekliligi-hakkinda> [Erişim Tarihi: 25.08.2019]. 
https://www.ingilizkonsoloslugu.org/ingiltere-vatandaslari-icin-turkiye-vatandasligi> [Erişim Tarihi: 05.02.2019].

Kastenholz, E., Carneiro, M. J., Eusébio, C., and Figueiredo, E. (2013). Host-Guest Relationships in Rural Tourism: Evidence from Two Portuguese Villages. Anatolia, An International Journal of Tourism and Hospitality Research, 24(3), 367-380.

Konuk, M. (2017). Sosyal İlişkilerde Güven (Malatya İli Örneği).,Yayınlanmamış Yüksek Lisans Tezi, İnönü Üniversitesi, Malatya.

Lee, Y., Kim, M., and Koo, J. (2016). The Impact of Social Interaction and Team Member Exchange on Sport Event Volunteer Management. Sport Management Review, Elsevier, 19(5), 550-562.

Mouratidis, K. (2018). Built Environment an Social Well-Being: How Does Urban Form Affect Social Life and Personal Relationships? Science Direct (74), 7-20.

Özgüneş, R.E. (2017). Destinasyon İmajının Yerleşik Yabancıların Yerleşim Yeri Seçimine Etkisi: Bodrum, Yayınlanmamış Yüksek Yüksek Lisans Tezi, Balıkesir Üniversitesi, Balıkesir.

Özgürel, G. ve Avcıkurt, C. (2018). Yerleşik Yabancıların Türkiye Turizmine Etkileri: Marmaris İlçesi Örneği. Seyahat ve Otel İşletmeciliği Dergisi, 15(1), 195-225.

Öztürk, Y. ve Özaslan, Y. (2013). Orta Öğretim Öğrencilerinin Yabancı Turistlere İlişkin Tutumları Üzerine Bir İnceleme. 14. Ulusal Turizm Kongresi'nde sunuldu (s. 1181-1198). Kayseri: Erciyes Üniversitesi Turizm Fakültesi Yayınları No:1.

Pizam, A., Uriely, N., and Reichel, A. (2000). The Intensity of Tourist-Host Social Relationship and Its Effects on Satisfaction and Change of Attitudes: The Case of Working Tourists in Israel. Tourism Management (21), 395-406.

Reisinger, Y., and Turner, L. (2003). Cross-Cultural Behavior in Tourism. Oxford, UK: Elsevier Science Limited.

Rızaoğlu, B. (2012). Turizm Davranışı (3. Basım). Ankara: Detay Yayıncılık.

Salant, P., and Dillman, D. A. (1994). How to Conduct Your Own Survey. New York: John Wiley \& Sons Inc.

Schumacker, R. E., and Lomax, R. G. (2004). A Beginner's Guide to Structural Equation Modeling (2nd Edition). New Jersey: Taylor\& Francis.

Sinkovics, R. R., and Penz, E. (2009). Social Distance between Residents and International Tourists-Implications for International Business. International Business Review (18), 457-469.

Sümer, N. (2000). Yapısal Eşitlik Modelleri: Temel Kavramlar ve Örnek Uygulamalar. Türk Psikoloji Yazıları, 3(6), 49-74.

Smith, K. M. (2011). The Relationship between Residential Satisfaction, Sense of Community, Sense of Belonging and Sense of Place in a Western Australian Urban Planned Community, Unpublished PhD Thesis, Edith Cowan University, Joondalup, Australia.

Şimşek, Ö. F. (2007). Yapısal Eşitlik Modellemesine Giriş- Temel İlkeler ve LISREL Uygulamaları. Ankara: Ekinoks.

Şirin, İ. (2017). Yerleşik Yabancıların Yerel Hizmetlere Bakışı: Alanya Örnĕ̆gi, Alanya Alaaddin Keykubat Üniversitesi, Alanya.

Tabachnick, B. G., and Fidel, L. S. (2013). Using Multivariate Statistics (6th Edition). Boston: Pearson Education Inc. 
Ural, A. ve K1lıç, İ. (2018) Bilimsel Araştırma Süreci ve SPSS ile Veri Analizi, Ankara: Detay Yayıncilik.

Urry, J. (2009). Turist Bakışı, (Çeviren, E. Tataroğlu ve İ. Yıldız), Ankara: Bilgesu Yayıncılık.

Yazan, T., Girgin, A. ve Kuru, T. (2017). Geriyatrik Depresyon: Alanya'da Yaşayan Yerleşik Yabancılar Üzerine Bir Araştırma. Acta Medica Alanya, 1(3), 32-37.

Yirik, Ş., Uslu, A. ve Küçük, F. (2015). Yerleşik Yabancıların Türkiye’ye İlişkin Sosyo Kültürel Algılarının Demografik Özelliklerine Göre İncelenmesi. Bartın Üniversitesi IIIBF Dergisi, 6(11), 263-282.

Waltz, C. F., Strickland, O. L., and Lenz, E. R. (2010). Measurement in Nursing and Health Research. (4th Edition). NewYork: Springer Publishing Company.

Wang, J., and Wang, X. (2012). Structural Equation Modeling: Applications Using Mplus. West Susex: John Wiley \& Sons.

Wang, Z., Zhang, F., and Wu, F. (2017). Neighborhood Cohesion under The Influx of Migrants in Shanghai. Environment and Planning A., 49(2), 407-425.

Weaver, D. B., and Lawton, L. J. (2001). Resident Perceptions in The Urban-Rural Fringe. Annals of Tourism Research, 28(2), 439-458.

Wu, L., Zang, J., and Chikaraishi, M. (2013). Representing the Influence of Multiple Social Interactions on Monthly Tourism. Tourism Management (36), 480-489.

Xu, H., Ma, S., and Jiang, L. (2017). Social Interactions of Lifestyle Tourism Entrepreneurial Migrants. Tourism Tribune, 32(7), 69-76.

Zhang, J., Inbakaran, R. J., and Jackson, M. S. (2006). Understanding Community Attitudes Towards Tourism and Host-Guest Interaction in the Urban-Rural Border Region. Tourism Geographies, 8(2), 182-204. 